\section{Language barriers contribute to health care disparities for Latinos in the United States of America ${ }^{1}$}

Key words: communication barriers, language, cultural diversity, disparities in health, physicianpatient relations, Hispanic Americans.

\footnotetext{
1 Based on: a) Robert Wood Johnson Foundation. New survey shows language barriers causing many Spanish-speaking Latinos to skip care [press release]. Princeton, New Jersey, United States of America: Robert Wood Johnson Foundation; 2001. Available from: http://www. rwjf.org [Internet site]. Accessed 17 December 2001; b) Robert Wood Johnson Foundation. Hablamos juntos-we speak together [call for proposals]. Princeton, New Jersey, United States of America: Robert Wood Johnson Foundation; 2001. Available from: http://www.rwjf.org [Internet site]. Accessed 17 December 2001; c) Wirthlin Worldwide. Hablamos juntos-we speak together. Research conducted for The Robert Wood Johnson Foundation [Internet page]. Princeton, New Jersey, United States of America: Robert Wood Johnson Foundation; 2001. Available from: http://www.rwjf. org [Internet site]. Accessed 17 December 2001; and d) Robert Wood Johnson Foundation. Language barriers and access to care [press conference transcript]. Available from: http://www.kaisernetwork. org/health_cast [Internet site]. Accessed 17 December 2001.
}

Difficulties that Spanish-speaking Latinos have in communicating with health care providers in the United States of America are contributing to inconsistencies in health care treatment and outcomes in that country, according to survey findings released in December 2001 by the Robert Wood Johnson Foundation (RWJF), a philanthropy that is based in Princeton, New Jersey, and that focuses its grantmaking on improving health and health care in the United States.

The survey was conducted for RWJF by Wirthlin Worldwide, a marketing and opinion research firm based in McLean, Virginia, a suburb of Washington, D.C. Wirthlin carried out telephone interviews in October and November of 2001 with 1001 health care providers, including physicians, nurses, hospital executives, and pharmacists. All of those providers indicated that at least $5 \%$ of their patient base was primarily Spanish-speaking. In addition, Wirthlin conducted telephone interviews in Spanish with 500 Latino adults. All of the providers and Latinos interviewed were from areas of the United States where Latinos now comprise more than $5 \%$ of the general population and where the number of Latinos grew by at least $75 \%$ between the 1990 and 2000 national census counts.

According to the United States Census Bureau (1), the number of persons of Hispanic or Latino heritage in the country rose from 22.4 million in 1990 to 35.3 million in 2000, an increase of $58 \%$. In comparison, the overall population of the United States grew by $13.2 \%$, reaching 281.4 million. As a proportion of the entire population in the country Latinos increased from $9.0 \%$ in 1990 to $12.5 \%$ in 2000 .

The Hispanic population is still concentrated in states of the West and the Southwest of the United States, along with two East Coast states, New York and Florida. Nevertheless, the states that experienced the largest percentage growths in the number of Latinos between 1990 and 2000 are in other parts of the country, including the South, Southeast, and Midwest. In 22 of the 50 states of the United States, the number of Hispanics more than doubled between the two census counts (2). In recent years many Latinos have been attracted to new areas of the United States because of better employment opportunities.

The RWJF survey focused on areas of the United States that experienced the largest growth in 
the number of Latino residents between 1990 and 2000. Many of those areas historically have not had large, well-established Hispanic populations and lack the experience and capacity that other parts of the United States have in meeting the needs of Spanish-speaking patients. "The health care systems in states such as North Carolina, Arkansas, Georgia, Tennessee, and Alabama [which are in the South and the Southeast] are now faced with infrastructure challenges in addressing the health care needs of this surging population," explained Risa Lavizzo-Mourey, senior vice president and director of RWJF's health care group.

Patients who experience language barriers are part of a growing population. The United States Census Bureau found in the 2000 population count that 26.7 million Latinos in the United States over the age of 5 years speak Spanish at home, with some 12.4 million of them speaking English less than "very well."

\section{COMMUNICATION DIFFICULTIES}

Both patients and providers believe that language barriers present serious obstacles to positive health outcomes, the RWJF survey found. According to patients, communication difficulties make it much harder to fully explain symptoms and to ask questions, to follow through with filling prescriptions, to believe that doctors understand their medical needs, to understand doctors' recommendations, and to see doctors as often as needed. In fact, $19 \%$ of the Latino adults surveyed reported that, due to language barriers, they had not sought care when they needed it.

The health care providers said that language difficulties make it harder for a patient to understand and follow through on the information that a doctor provides on a medical condition or disease, and also increase the risk that a doctor will not learn about some medication or home remedy that a patient is using. Language barriers also make it more difficult for the doctor to compile a complete, accurate medical history.

The RWJF research found that when languageinterpretation help is offered, it is often improvised or "makeshift." Fifty-one percent of the providers surveyed said that they often enlist help from staff members who speak Spanish, including clerical and maintenance personnel such as receptionists and even janitors. Another $29 \%$ said they rely on patients to bring in family members or friends who can translate for them. Another $15 \%$ of the providers said they retain an outside group to provide interpreting services either on-site or remotely, such as over the telephone. Another $4 \%$ of the providers said that their organizations provide foreign-language training for their health professionals.

Patients told the surveyors that makeshift interpretation practices, such as using family members or untrained staff, often leave them feeling embarrassed, that their privacy has been compromised, and that the interpreters have omitted information. The Latino survey respondents also said these concerns cause them not to talk about personal issues when interpreters are present.

Cost is the single most important obstacle for organizations trying to overcome the language problems faced by Spanish-speaking patients, according to the health care providers who responded to the RWJF survey. That barrier was mentioned by $53 \%$ of the providers. A variety of other factors were mentioned, but much less frequently. Among these were: the problem is not a priority for the institution $(13 \%$ of the respondents); there are no foreign-language skills on the staff $(6 \%)$; a lack of training or knowledge of how to meet the language needs $(6 \%)$; no resources or ideas for dealing with the problem $(6 \%)$; and not enough time available $(6 \%)$.

\section{RESEARCH INITIATIVE}

"Medical [interpretation] is complicated and subtle," said Yolanda Partida, who is directing a new RWJF initiative called Hablamos Juntos ("We Speak Together"), which seeks to improve communications between health care providers and Latino patients. "The fact that nearly two-thirds of the patients in this [RWJF] survey have concerns about using interpreters indicates that these makeshift approaches are not working."

The new project is aimed at developing effective and affordable models using trained interpretation and translation services to help providers surmount language barriers. "The solutions to these problems are not clear," Partida said. "We are at an early stage in our understanding of how best to provide and pay for interpretation services." To learn more, the project will provide grants so health care providers can research ways to overcome existing language barriers in geographic areas with fast-growing Hispanic populations (see the sidebar entitled "Grants available to develop, test systems to overcome language difficulties").

"Hablamos Juntos is a starting point," said Lavizzo-Mourey. "We chose to focus on Spanish because of the size and growth of the Spanish-speaking population in the [United States]. But we hope that what we learn through this program will help patients and providers who encounter barriers from other languages." 


\section{Grants available to develop, test systems to overcome language difficulties}

To go beyond the research that it has done assessing the language barriers that Spanish-speaking persons face with health care in the United States of America, the Robert Wood Johnson Foundation has established a new program called Hablamos Juntos ("We Speak Together"). One of that program's activities will be to provide grants that will allow health care organizations to investigate cost-effective ways to overcome existing language barriers.

Hablamos Juntos will provide grants of up to US\$1 million each to as many as 10 different health care provider organizations in communities or catchment areas with new and fast-growing Latino populations. Grant recipients will use the funds to develop and test systems of medical interpretation, signage, and print materials. To be eligible for the program, applicants must serve a community, city, county, or catchment area that had a Latino population of at least 10000 persons in 2000 and that experienced at least a $50 \%$ growth in Latino population from 1990 to 2000.

The program is open to various types of provider organizations, including physician groups, commu- nity health centers, hospitals, state Medicaid agencies, health plans, managed care plans, local health authorities, health profession organizations, or a consortium of these organizations.

The grants will be awarded in two phases: a oneyear, first phase for organization and planning, and a second, two-year phase for implementation of the proposed activities. Institutions or organizations that are interested in receiving Hablamos Juntos funding must first submit a letter of intent that briefly describes the proposed activities. From those expressions of interest, Hablamos Juntos will select a group of candidates and ask them to submit a full proposal for the first, one-year planning phase. The deadline for submitting a letter of interest is 1 February 2002. Inquiries concerning the program should be directed to: Yolanda Partida, Program Director, Hablamos Juntos, Tomás Rivera Policy Institute, 1050 North Mills Avenue, Pitzer College, Scott Hall, Claremont, California. More information is also available by telephoning (909) 607-9834 or from the group's web site, http://www.hablamosjuntos.org.

\section{SINOPSIS}

\section{Las barreras lingüísticas contribuyen a las disparidades de la asistencia sanitaria de los hispanos en los Estados Unidos de América}

Las dificultades de los hispanohablantes para comunicarse con los profesionales sanitarios de los Estados Unidos de América (EE. UU.) son uno de los factores que contribuyen a las disparidades de la asistencia sanitaria y de sus resultados en este país. Esa es la conclusión que se deriva de los resultados de una encuesta publicados en diciembre del 2001 por una organización filantrópica dedicada a mejorar la salud y la asistencia sanitaria de la población de los EE. UU. La encuesta se basó en entrevistas telefónicas de profesionales de la salud y adultos hispanohablantes de zonas de los EE. UU. que han tenido en los últimos años un gran aumento del número de residentes hispanos. Según los hispanos entrevistados, los problemas de comunicación les hacen mucho más difícil explicar sus sintomas, hacer preguntas, conseguir los medicamentos que les ha prescrito el médico o creer que los médicos han comprendido sus necesidades médicas. Los profesionales sanitarios dijeron que esos problemas le dificultan al paciente la comprensión de la información proporcionada por el médico acerca de las enfermedad y el cumplimiento de sus instrucciones, además de incrementar el riesgo de que el médico no tome conocimiento de las medicaciones o remedios caseros que el paciente pueda estar tomando. Aun cuando haya ayuda de un intérprete, generalmente es improvisada y temporal. El 51\% de los profesionales entrevistados dijeron que a menudo buscaban la ayuda de un intérprete entre el personal hispanohablante, incluido el personal auxiliar y de mantenimiento, como recepcionistas o conserjes. Con el fin de ayudar a resolver estos problemas de comunicación, la organización filantrópica en cuestión, la Fundación Robert Wood Johnson, ha lanzado una nueva iniciativa, denominada Hablamos Juntos, que tratará de mejorar la comunicación entre los profesionales sanitarios y los pacientes hispanos.

\section{REFERENCES}

1. Guzmán B. The Hispanic population. Census 2000 brief. Washington, D.C.: United States Census Bureau; 2001. Available from: http://www.census.gov [Internet site]. Accessed 19 December 2001.
2. Cook B. Old town, nuevos patients: smalltown doctors treating influx of Hispanic immigrants. American Medical News 2001;44(37). Available from: http:// www.ama-assn.org/public/journals/ amnews/amnews.htm [Internet site]. Accessed 19 December 2001. 